Int. J. Electrochem. Sci., 15 (2020) $2851-2862$

\title{
Effect of Saccharose Concentration and Temperature on the Internal Stress and Corrosion Resistance of Electroplated Chromium Coatings Prepared from Chromium (III) Bath
}

\author{
Hung-Hua Sheu, ${ }^{1,2, *}$, Yuan-Rong Chen ${ }^{1}$, Ming-Der Ger ${ }^{1,2, *}$ \\ ${ }^{1}$ Department of Chemical and Materials Engineering, Chung Cheng Institute of Technology, National \\ Defense University, Taoyuan City, Taiwan \\ ${ }^{2}$ System Engineering and Technology Program, National Chiao Tung University, Hsin-Chu, Taiwan \\ *E-mail: shhccit@gmail.com, mingderger@gmail.com
}

doi: $10.20964 / 2020.04 .12$

Received: 29 November 2019 / Accepted: 2 February 2020 / Published: 10 March 2020

The trivalent chromium carbon coatings are electroplated from different electroplating temperature (10, 0 and $\left.-5^{\circ} \mathrm{C}\right)$ and different concentration $(0.01,0.02$ and $0.03 \mathrm{M})$ of saccharose $\left(\mathrm{C}_{12} \mathrm{H}_{22} \mathrm{O}_{11}\right)$. The saccharose play a role of stress inhibitor in the bath during electroplating process. The results of internal stress analysis show that the internal stress of the trivalent chromium carbon coating decreases with the increase of concentration of saccharose at individual electroplating temperatures, this shows that saccharose has the effect on suppressing the accumulation of stress within the coating. Moreover, the electroplating temperature also affect the internal stress of trivalent chromium carbon coatings i.e. the lower electroplating temperature $\left(-5^{\circ} \mathrm{C}\right)$ will reduce the accumulation of stress within the coating during electroplating. The smallest internal stress of trivalent chromium carbon coatings is $13.4 \mathrm{MPa}$, electroplated at $-5^{\circ} \mathrm{C}$ with a concentration of saccharose at $0.02 \mathrm{M}$. The best $\mathrm{i}_{\text {corr }}$ is approximately at $1.32 \times 10^{-6} \mathrm{~A} / \mathrm{dm}^{2}$, this coatings is also electroplated at $-5^{\circ} \mathrm{C}$ and the concentration of saccharose at 0.02 $\mathrm{M}$. The results indicated that both electroplating temperature and concentration of saccharose can reduce the internal stress within trivalent chromium carbon coatings and decrease the through-deposit cracking within coatings, thereby improving the corrosion resistance of coatings.

Keywords: trivalent chromium carbon coatings, internal stress, electroplating temperature

\section{$\underline{\text { FULL TEXT }}$}

(C) 2020 The Authors. Published by ESG (www.electrochemsci.org). This article is an open access article distributed under the terms and conditions of the Creative Commons Attribution license (http://creativecommons.org/licenses/by/4.0/). 